\title{
Correction to: Measuring the supporting slats of laser cutting machines using laser triangulation
}

\author{
Frederick Struckmeier ${ }^{1,2} \cdot \operatorname{Jim}$ Zhao $^{1} \cdot$ Fernando Puente León $^{2}$ \\ Published online: 2 June 2021 \\ (C) Springer-Verlag London Ltd., part of Springer Nature 2021
}

\section{Correction to: The International Journal of Advanced Manufacturing Technology (2020) 108:3819-3833 https://doi.org/10.1007/s00170-020-05640-Z}

The article Measuring the supporting slats of laser cutting machines using laser triangulation, written by Frederick Struckmeier, Jim Zhao and Fernando Puente León, was originally published Online First without Open Access. After publication in volume 108, issue 11-12, page 3819-3833 the author decided to opt for Open Choice and to make the article an Open Access publication. Therefore, the copyright of the article has been changed to (OThe Author(s) 2021 and the article is forthwith distributed under the terms of the Creative Commons Attribution 4.0 International License, which permits use, sharing, adaptation, distribution and reproduction in any medium or format, as long as you give appropriate credit to the original author(s) and the source, provide a link to the Creative Commons licence, and indicate if changes were made. The images or other third party material in this article are included in the article's Creative Commons licence, unless indicated otherwise in a credit line to the material. If material is not included in the article's Creative Commons licence and your intended use is not permitted by statutory regulation or exceeds the permitted use, you will need to obtain permission directly from the copyright holder. To view a copy of this licence, visit http://creativecommons.org/licenses/by/4.0.

Publisher's note Springer Nature remains neutral with regard to jurisdictional claims in published maps and institutional affiliations.

The online version of the original article can be found at https://doi.org/ $10.1007 / \mathrm{s} 00170-020-05640-\mathrm{z}$

Frederick Struckmeier

frederick.struckmeier@kit.edu

1 TRUMPF Werkzeugmaschinen GmbH, Co. KG, Johann-Maus-Str. 2, 71254 Ditzingen, Germany

2 Karlsruhe Institute of Technology, Institute of Industrial, Information Technology, Hertzstr. 16, 76187 Karlsruhe, Germany 